\title{
EXPATRIATION INTO AND OUT OF EMERGING MARKETS: CHALLENGES FOR IHRM
}

\section{Abstract}

Increasingly, the focus of global business is on emerging - or growth - markets. Up to now, most research in IHRM has focused on management of expatriates from MNEs headquartered in developed countries to positions in subsidiaries in other developed countries. If the research involved expatriate experiences in emerging markets, that fact was rarely mentioned and even more rarely focused on as a significant issue. In this article, I present a review of the literature involving the assignment of expatriates by developed-country MNEs to subsidiaries in emerging markets plus an overview of the literature that now examines the use of expatriates by emerging-market MNEs. First, I define the nature and use of the term "emerging markets". For practical discussion and research purposes, this term is too broad. Then I review the limited literature on expatriation from developed-country MNEs into emerging-market subsidiaries, assess the research on comparisons between developed-market assignments and emerging-market assignments, and evaluate the newly-developing focus on expatriates from emerging-market-based MNEs who are being assigned to subsidiaries in either other emerging markets or to subsidiaries in developed markets. At the end of the article, I review a number of recent surveys by consulting firms of the challenges MNEs are experiencing today with their assignments of employees to positions in emerging markets and assess whether these experiences are different than prior assignments of expatriates to developed markets and suggest some solutions to the challenges being experienced.

Keywords: MNEs, emerging markets, expatriation, international HRM. 


\section{Introduction}

Over the last 10 to 20 years, increasing attention has been devoted to research in International Human Resource Management (IHRM) and its siblings, Human Resource Management (HRM) in multinational enterprises (MNEs), and comparisons of HRM practices in various countries ${ }^{1}$. However, as has been often stated, most of this research has been centred in developed countries (mostly northern and western) and/or has been conducted by researchers from the West or who have been trained at western universities and has been conducted primarily in multinational enterprises from developed countries (and largely in their subsidiaries in other developed countries) ${ }^{2}$. As a consequence, most of the research has centred on the practices of MNEs from developed countries. And because until quite recently most global trade was between developed countries, little research focused on issues related to the behaviour of MNEs in developing countries - and particularly not on the use of expatriates in developing countries. This article intends to address this issue, examining and analysing the management of expatriates in developing countries or emerging markets.

In existing research efforts, largely centred on developed countries, it has been observed that:

Some of the HR tasks involved in globalisation are much the same as domestic tasks, only more complex. For example, workers must be selected, trained, and compensated in either setting. However, many more uncertainties abound in cross-national settings. [For example,] do the same personal traits predict success in different cultures? Can they be assessed via similar methods? How can customer service employees be trained to respond appropriately to the tacit understanding that exists in another culture? Which parts of a job embody strategic knowledge or skills that should not be outsourced, and which represent knowledge or skills that might best be commoditised? (Rynes, Brief \& Walsh 2008, p. i.)

Most multinational enterprises (MNEs) find it necessary to send their headquarters-based employees (expatriates or parent country nationals PCNs) to their foreign operations to handle key positions such as start-up manager, technology transfer, product marketing, accountant, and managing

\footnotetext{
${ }^{1}$ See, for example: Brewster \& Mayrhofer (2012); Briscoe, Schuler \& Tarique (2012); Budhwar \& Debrah (2001b); Budhwar, Schuler \& Sparrow (2009); Dowling et al. (2013); Harris (2008); Harzing \& Pinnington (2011); Rowley \& Warner (2008); Scholz \& Böhm (2008); Schuler et al. (2004-12); Sparrow, Brewster \& Harris (2012); Stahl, Björkman \& Morris (2012); Thomas \& Lazarova (2013); and Wilkinson et al. (2010).

${ }^{2}$ See, for example: Harris (2008); Morris \& Snell (2010); Sparrow (2009); and Stahl, Björkman \& Morris (2012).
} 
director, at least in the early stages of their internationalisation efforts. Consequently, much of the research on IHRM topics has been concerned with the management and role of expatriates or PCNs. Alternatively, MNEs may hire local talent (host country nationals - HCNs) or talent from third countries (third country nationals - TCNs) for these types of responsibilities - but typically only when they have to for strategic or practical reasons (such as when required by the host country), although the management of these latter two types of employees has been studied far less.

As this article discusses, very little of the research on global staffing has been conducted in developing countries (or, to use a more recent term, emerging markets). Thus, there is little knowledge to help determine whether issues related to the recruitment, selection, training, management, and repatriation of expatriates assigned to subsidiaries or joint ventures in emerging economies are different from those issues as experienced when assigning PCNs to subsidiaries in developed economies, or for that matter, different from those issues in MNEs from developing economies.

Thus, the challenge for this article is to examine the literature on the use and management of expatriates either going to or coming from emerging markets. What do we know and what would it be good to learn? Are the factors that validly identify managers or other employees for international assignments in developed economies different from such factors for identifying successful expatriates for assignments in developing countries? Are expatriate experiences in assignments in developing countries different from their experiences in developed countries? Are performance and subsequent failure rates and experiences different for expatriates assigned to developing countries than for those assigned to developed countries? Are there special types of expatriates that perform better and produce fewer failures in assignments in developing countries? If so, what are the characteristics of such expatriates? Do MNEs have different reasons to use expatriates in their emerging market subsidiaries, acquisitions, and joint ventures than are active for assignment of expatriates to positions in developed countries? Are support systems different - or should they be different? Do pre-relocation preparations and training need to be different? And what about MNEs in emerging markets who consider and/or send expatriates from the developing country firm to assignments in either other developing countries or to developed countries - are their experiences different from those of MNEs from developed countries? 


\section{Defining and Differentiating Developed Economies from Developing Economies}

My first task is to differentiate various types of emerging markets and to differentiate developed countries from developing countries for the purposes of this paper ${ }^{3}$.

The overall focus of the article is on the management of expatriates in emerging economies. So it is important to make clear which countries are being considered.

\section{Developed Economies}

The world's largest and most highly developed economies (usually based on per capita GDP, as used, for example, to accept - among other factors - countries to become members of the Organisation for Economic Cooperation and Development - OECD) are primarily located in Western Europe and North America, with the exceptions of Japan (the world's third largest economy, having recently been bumped from number two by China), Australia, and New Zealand (and recently South Korea), in Asia Pacific. Most of the published research reviewed in this article was accomplished in MNEs from developed countries. Nevertheless, there is a growing body of research conducted in MNEs from smaller and often developing countries - now largely referred to as emerging markets. An attempt has been made to locate and describe this literature. The following is a short summary of terminology used to describe groups of countries that in recent years have been identified as fast-growing, emerging markets.

\section{Asian Tigers}

The first countries that moved from undeveloped status to developed status were the countries referred to as the Asian Tigers, including South Korea, Hong Kong, Singapore, and Taiwan. These countries were described in the business media in the late 1960s to experience the move from developing to developed country status. They exhibited export-driven, high economic growth rates from the 1960s to the 1990s which led to their moving rapidly from developing economy status to high-income, highly-developed economies. Much of this growth was due to national priorities set on investments in education, infrastructure, and focused expenditures on specific manufacturing sectors that could produce significant exports.

| $\quad{ }^{3}$ Cf. Beamish (1988); Budhwar \& Debrah (2001a); and Horwitz \& Budhwar (2015). 


\section{Asian Tiger Cubs}

More recently, additional Asian countries, identified as the Asian Tiger Cub Economies, were seen as becoming "emerging markets": Indonesia, Malaysia, Philippines, and Thailand.

\section{BRICS}

Most recently, the countries called the BRICS (Brazil, Russia, India, China, and South Africa) have received close attention. The term was created in 2001 (originally only BRIC) by Jim O'Neill (2001) in a special report from Goldman Sachs to describe four large-population emerging economies that were experiencing high growth rates and were impacting overall global trade and economic growth rates. South Africa has been recently added to the term.

The N-11

Now, journals and consultants have begun to focus on the next group of countries which might join the Tigers and BRICS. Some writers use the term MIST (Mexico, Indonesia, South Korea, and Turkey) and others expand the list to the Next 11 (sometimes referred to as the N-11) (Bailey 2010): Mexico, Indonesia, Vietnam, Philippines, Iran, Nigeria, Egypt, Pakistan, Turkey, Bangladesh (and sometimes South Korea, which technically is often now viewed as a developed economy).

Other terminology I have run across to describe emerging markets or developing economies includes CIVETS - Columbia, Indonesia, Vietnam, Egypt, Turkey, South Africa; MIKT - Mexico, Indonesia, South Korea, Turkey; and EMNEs - Emerging Market MNEs. Obviously, the specific interests or knowledge of the authors influences which countries they want to include in their acronym and focus.

\section{Africa and Latin America}

Interestingly, none of these groups of emerging markets includes any countries from central Africa (or, for that matter, more than a couple from Latin America). I have no idea why countries of Latin America are largely ignored. It seems to me that some Latin American economies, other than Mexico and Brazil, which are usually mentioned, ought to also be included, such as Peru, Chile, maybe Argentina, and other smaller countries, such as Ecuador and Columbia. In the case of Africa, in recent years, sub-Saharan Africa has been experiencing foreign direct investment (FDI) among 
the highest in the world and a collective economic growth rate among the highest. As major firms seek both new markets and lowest-cost centres for outsourcing and sub-contracted manufacturing, Africa presents maybe the last good location for investment (United Nations Human Development Reports 2011, Kupka, Briscoe \& Everett 2013a, 2013b).

In the case of both Africa and Latin America, a young, dynamic, and growing general population, an expanding middle class, plentiful commodities valuable to the world economy such as 30\% - in Africa and at least as much in Latin America - of the world's mineral reserves and a wealth of energy resources (Ibrahim 2010), and investments in infrastructure in various countries give hope for a brighter future (Knowledge at Wharton 2010) and have led to GDP Growth rates among the world's highest (Roxburgh et al. 2010). Thus, it is necessary to include Africa and Latin America in any analyses of HRM practices in emerging economies.

\section{Emerging Market Economies}

Even though it may seem as though the interest in emerging markets is quite recent, other terms for analysis and discussion of developing countries have been used for many years, such as less-developed, least developed, third world, developing, and, more recently, emerging markets, growth markets, and fast-growth markets. In this article I primarily use the terms "developing countries" and "emerging markets", indicating earlier and more recent terms. This shows that I am interested in both earlier and current literature on the use of expatriates in developing countries.

Collectively, these countries (emerging markets) are beginning to dominate global trade. Obviously, they cannot be analysed as a single entity. So any discussion of the use of expatriates in "emerging economies" must accommodate the reality that there are many, highly varying, emerging economies. Two of the surveys reported in this article, by consulting firms Ernst \& Young (2012a, 2012b; Meinert 2013) and Brookfield (Hauser \& Aldred 2012) now refer to these countries collectively as growth markets or fast-growth markets. As these reports indicate, expatriate management for any one emerging market may well have to be quite different from practices in any others. An additional reason for this has to do with the typical significant cultural distance of developed countries from developing countries, let alone the differences between the developing countries, thus creating extra difficulties in expatriate adjustment in developing country assignments that are likely to be more significant than those experienced by expatriates on assignment in developed countries. 
As the previous section describing the various emerging markets illustrates how varied and numerous these countries are, it makes sense to me to primarily organise these countries geographically, rather than by the levels of development currently being used; that is, it makes sense to organise and analyse developing markets into these regions: Asia Pacific, Central Asia, Middle East, Africa, Europe, and Latin America. This may also have the effect of grouping countries for attention with similar cultures. Of course, there will be some exceptions to this, but such an organisational scheme should help simplify some of the many complexities encountered in doing research on these countries.

\section{Expatriates in Emerging Markets}

In a recent practitioner-oriented survey, consulting firm Ernst \& Young (2012, 2012b; Meinert 2013) focused on the management of expatriates in developing countries. The fact that Ernst \& Young now finds it important to survey their clients on this topic illustrates that emerging markets are finally being viewed as so important to the success of MNEs that firms like Ernst \& Young need to focus directly on these countries. This is a recent phenomenon. And as a major consequence of such focus, not only is Ernst \& Young examining this topic from the stand point of its clients, they are also examining their own practice of International Human Resource Management (IHRM) as it deals with the broadened scope of the firm's global workforce, for example, their own use of expatriates in their increasing number of offices in these emerging (fast-growth) economies. The Rapid-Growth Markets Forecast (Ernst \& Young 2012a) found that the MNEs surveyed predicted that nearly half of global growth will come from developing markets in the next few years. Many companies are staking their future prosperity on developing markets, which despite recent slowdowns, still provide the world's growth engines. And, of importance to IHRM, these firms recognise that "(...) strategic ambition in growth markets can only be achieved with the right team" (Ernst \& Young 2012b, p. 35). But, "[g]ood people are hard to find... In rapid-growth markets, increased competition for talent from local players compounds the problem. Developed markets have too many candidates for too few jobs; rapid-growth markets may offer plentiful labour, but the skills available may not match those required" (Ernst \& Young 2012b, p. 35). 
The Ernst \& Young (2012a) survey showed that:

1. Expanding into new markets is now the primary reason for cross-border mobility, with $50 \%$ of companies surveyed citing it as the first or second driver for international moves.

2. In 2012, almost half of the companies surveyed (48\%) raised the number of people they sent to growth markets in comparison to other locations. This growth market focus is particularly clear in sectors that exploit natural resources, such as mining and oil and gas.

3. A Further $42 \%$ maintained the same level of growth market placements as seen in the 2011 survey, which was itself a year when the majority of respondents sent increased numbers to these regions.

4. Six out of ten respondents expect this trend to continue, and anticipate a further increase in deployment to growth regions in the next two to three years. It is foreseen that in 2015 the assignments in BRIC countries and Africa will increase by $13 \%$ to $56 \%$.

5. Within the growth countries, China is the most common destination (as was the case in the 2011 survey), followed by Africa and India.

As this survey shows, the use of expatriates is increasing in assignments to developing economies, illustrating how important it is to understand the challenges presented by this group of global staffers.

\section{Types of Organisations that Use Expatriates}

Most of the research on expatriates has been based in MNEs which are largely equity-based, publically-owned, large business organisations. However, there are many other organisations that also have experience with expatriates and thus offer possible sites for research on the mobility of employees from one country to another.

The primary focus in this article is on (1) global business enterprises (MNEs) that send expatriates from their developed economies to assignments in developing economies and (2) global business organisations from emerging markets (developing economies) that send expatriates to their operations in developed countries or other developing countries. Nevertheless, the management of expatriates is quite similar in all of the types of organisations listed here. These include the following:

- multinational enterprises (MNEs),

- non governmental organisations (NGOs),

- national government agencies (e.g. state departments, embassies, USAID), 
- international government agencies and trade groups,

- religious organisations.

This article focuses almost exclusively on MNEs, but presumably, the managers of "expatriates" in these various organisations could learn a lot from each other.

\section{Literature Review}

\section{Management of Expatriates from Developed Countries Assigned to MNE} Subsidiaries in Emerging Markets

Even though research on expatriates is the single largest focus of research in IHRM, there has been very little research on the subject of expatriates specifically on assignment in emerging markets. For example, in the Sparrow (2009) edited volume on IHRM, in 500 pages and 22 chapters, most of which is about the nature and role of expatriates, there is only one short discussion of the use of expatriates in developing economies - and that refers to the use of expatriates by NGOs.

Collings and Scullion (2006) provide a good summary of the pros and cons of using the three primary types of international employees (PCNs, HCNs, and TCNs), yet nothing is included about the possible differences between assignment to a developed country vis-à-vis to a developing country. Collings and Scullion (2006, 2012) discuss the varying use of PCNs, $\mathrm{HCNs}$, and TCNs from the perspective of a number of variables, including differences in the home and host countries, the nationality of the parent organisation, cultural distance between the host and home countries, type of ownership of foreign operation (wholly-owned subsidiary, joint venture), the age of the subsidiary operation, and industry. For example, "[t]he most consistent predictor of PCN [expatriate] presence or otherwise in foreign subsidiaries is the HQ country of origin" (Collings \& Scullion 2006, p. 32). On one extreme (highest use of expatriates) are the Japanese, close behind are the Europeans, followed by the US. At the time of their research, there was little or no research published on the use of expatriates by MNEs from developing countries, such as the BRIC countries (there is some now, which will be discussed later in this article).

Even though most of the research on the use of PCNs has been pursued in MNEs from developed countries with subsidiaries in other developed countries, there has been some limited research that focuses on (or refers 
to) the use of expatriate assignments in developing countries ${ }^{4}$. This section reviews this limited literature. Boyacigillar (1990) and Harzing (2001) indicate that the literature on the use of expatriates pointed to a lack of suitably qualified HCNs, particularly in developing countries, thus a need for the use of PCN expatriates in key positions (such as managing directors) by the MNEs from developed countries. In addition, significant cultural distance between the home and host countries (such as is typically the case between developed country MNEs and developing country host subsidiaries) has been linked to the use of PCNs in key positions in subsidiary operations (Boyacigillar 1990, Gong 2003). Even so, Harvey, Speier, and Novecevic (2001) argue that assignments in developing countries may represent extra-challenging assignments for PCNs, particularly in terms of cultural adjustment and quality of life issues (an issue which shows up in current global HR practitioner surveys, as well-described later in this article).

Gaining knowledge of the factors which influence the use of expatriates in developing countries, particularly those identified as emerging economies, i.e. those "which have liberalised their economies and opened their doors to foreign investors" (Budhwar \& Debrah 2001a, p. 3) would help MNEs manage the transferability of management and HR systems and practices. Regrettably, most of the literature on expatriates does not differentiate between developed and developing country assignments. Stahl, Miller \& Tung (2002) discuss job choice based on geographical location, yet do not specifically mention the role of cultural distance or differences between developed and developing country assignments. The focus of this research is on the choice of whether or not to accept a foreign assignment (not examining such a choice in the context of differences between developed or developing countries). Tung (1981) examined issues related to the selection and training of employees for overseas assignments. But, again, there is no discussion of the importance of the level of development of the host countries - only use of the language of "similarity of cultures" versus "highly diverse cultures."

Li, Wang, and Liu (2013) found that locally-recruited R\&D personnel in multinational (from developed countries) subsidiaries in an emerging economy made only a limited contribution in innovations and $R \& D$ output which then led to a strong reliance on R\&D expatriates from the parent firm. Research on comparative HR systems or global/local distinctions in HR practice are valuable but do not address issues of how firms might manage

${ }^{4}$ See, for example: Boyacigillar (1990); Briscoe (2015); Budhwar \& Debrah (2010); Collings \& Scullion (2012); Harzing (2001); Jones (2012); and Li, Wang \& Liu (2013). 
the increasing heterogeneity and uniqueness found across geographically dispersed workforces within a firm - particularly between developed and developing country operations (Morris \& Snell 2010). HR must develop the abilities to adapt to local talent pool needs but at the same time be able to coordinate and integrate these talent pools in ways that lead to economies of scale and scope, including - maybe, initially, primarily - the assignment of expatriates from HQ to new emerging market operations.

All of these concerns are enhanced in situations where MNEs use expatriates in outsourcing and offshoring situations (most often located in low-cost emerging markets) for control and technology-transfer purposes (Connelly \& Gallagher 2006, Fisher et al. 2008, Lewin \& Peeters 2006, Matusik \& Hill 1998). The performance of outsourced work creates complexities in supervisory, reporting, and interpersonal relationships that can lead to problems in both the MNE as well as the subcontractor, which can lead to the decision to use expatriates to alleviate these problems, that is, to provide better communication and control.

Jung, Beamish, and Goerzen (2008) and Beamish (1985) found two things that strongly influence an MNE's approach to foreign direct investment and the ensuing use of expatriates in their foreign joint ventures: the nationality of the MNEs and the nationality of the receiving countries. In terms of the sending countries, Japanese MNEs were most likely to use expatriates, followed by European (Western European) MNEs, and then followed by the US. But Japanese put most effort into selection and preparation and support, thus they report the best records related to failure and early return. Although these results probably apply to investments in both developed countries as well as in developing countries, most of the time little is said in research projects about where the subsidiaries or JVs are located. In terms of recipient countries, many - particularly developing economies - require use of joint ventures, often limiting the percentage of foreign equity. And often, because of these constraints, the foreign partners are limited in their use of expatriates.

In the case of NGOs, there is a long history of using expatriates (Fenwick 2005), but NGOs appear to have a philosophical agenda towards building local capacity that results in reliance on staffing with host country nationals (Salm 1999).

So, as many of these types of studies indicate, in order to be successful, developed country operations in developing economies need to focus on certain characteristics of their key position expatriates, probably more so than is the case in their subsidiaries in developed countries. 
Research here is often based on experience in one country. For example, Hieu (2013) reports on a study of three Vietnamese JV's. The results are generalised and deal with problems with interaction between the Vietnamese partners and their foreign partners. Even though the research does not put issues into developed versus developing country frameworks (although this language is used), it is clear that the results point to issues that should be of concern to foreign firms wanting to invest (through JVs, as required) in Vietnam.

Based on the conclusions, managers should consider the following things that can serve as guidelines for avoiding potential problems and conflicts in operating JVs in Vietnam. First, partners and respective managers of JVs in Vietnam must understand and trust each other (which, of course, is a major concern in any international JV). The following should be considered by both partners: (1) understanding and respecting cultural differences; (2) understanding the business practices of each partner, and then changing and adapting to the acceptable ones; and (3) maintaining an open dialogue between partners during the operation of the JVs because "by communicating more and more you solve the differences", as stated by one of the JV foreign general managers in the study (Hieu 2013, p. 60).

In a different country, Ruiz, Wang, and Hamlin (2013) report on their research on the effectiveness of managers in Mexico, including expatriates. As they indicate, the increasing number of expatriates working in Mexico, coupled with the recognised shortage of competent managerial resources in Mexico, provide compelling reasons for examining this issue as well as for identifying selection and training protocols for expatriates from MNEs operating in Mexico. They found that effective managers in Mexico are considered approachable, democratic, fair, considerate, understanding, supportive, caring, and hard working with problem solving skills. Even though this sounds like a description of a perfect manager, the authors suggest that firms sending managers to Mexico can use some of these characteristics for selecting the right assignees. And they can use these characteristics in pre-relocation training to prepare their expatriates for assignment to Mexico.

\section{Use of Expatriates by Emerging Market Firms}

There has been very little literature on this topic (cf. Sim 2012; Thite, Wilkinson \& Budhwar 2011a, 2011b). Even so, as emerging markets grow and develop MNEs themselves, questions about how the flow of expatriates 
works in the other direction are also of interest (e.g. in firms such as Tata motors from India, InfoSys from India, Good Baby from China, Embraer from Brazil).

If there is one country which has received the most attention from researchers, it is China. For example, Gammeltoft and Tarmidi (2013) report on a study of Chinese FDI in Indonesia, illustrating the benefits for Indonesia of such investment (such as investments in logistics, travel, and banking). But as is so often the case, there is no direct discussion of the Chinese use of expatriates in their staffing in Indonesia, even though such practices by the Chinese are often observed in their investments in other developing countries (cf. Kupka, Briscoe \& Everett 2013a, 2013b).

Jie (2010) and Qi (2013) found Chinese MNCs most likely to use "talent localisation" rather than expats, although experience with Chinese firms in Africa shows a tendency to staff with Chinese expatriate workers and managers, at least in North Africa (Kupka, Briscoe \& Everett 2013b), most likely due to lack of Chinese experience and therefore a consequent lack of trust in local partners.

Yao (2013) indicates that Chinese expatriates find their initial expectations to be fulfilled, yet over time other factors affect their perceptions of the value of their international assignments. While Chinese assignees appreciate their international experiences, they consider that they have little impact on their future careers.

\section{Recent Practitioner / MNE Research on the Use of Expats in Developing Economies}

There are a number of surveys by large global consultancies of MNE experiences, attitudes, and policies concerning relocation and mobility trends ${ }^{5}$. Among other things, these surveys indicated the following:

a) growth markets are fuelling the increase in assignments, especially to China, India, and Africa,

b) personal rather than professional issues continue to be by far the most significant factors in failed assignments and dissatisfied assignees,

c) the number of assignments to growth market countries have increased on average by $16 \%$ from 2011 and will further rise by $27 \%$ in the next three years.

${ }^{5}$ Recent surveys include: Ernst \& Young's (2012a, 2012b); Circle Research for the Santa Fe Group (2013); Brazier (2013); PwC (Maurer 2013b); the Cartus Group (Maurer 2013a); and the Brookfield Group (Aldrich 2013, Ladika 2013). 
Questions about assignees' experiences in relocating to developing locations and in repatriating, included:

- these being the most challenging locations for expatriates;

- differences in managing global mobility to less developed locations vs more developed locations;

- phases of an assignment that pose a challenge for expatriation to developing locations - for example, candidate selection, pre-departure preparation, relocation, on-assignment support, compensation and benefits, and repatriation - and the steps taken to address them;

- talent management and post-repatriation career planning considerations for assignees going to and returning from developing locations;

- family considerations and programmes or approaches introduced to meet the needs of families going to (or returning from) developing locations;

-different challenges for different assignment types - long term, short term, developmental, etc., and

- specific needs raised by business leaders when seeking to send employees on assignment to locations where the company does not have support on the ground.

As the work on these surveys progressed, more specific issues arose that were examined in detail:

- recruiting employees for assignments in developing locations,

- assignment location challenges,

- compensating employees undertaking assignments in developing locations, and

- immigration challenges.

So... how did firms define a location as developing? The answers were quite practical:

- non-existent expatriate housing,

- limited or non-existent education facilities for accompanying dependents,

- accessibility and transportation challenges,

- rudimentary medical facilities,

- vast cultural differences,

- significant language barriers,

- unreliable power and water supply infrastructure,

- government or regulatory environments that are difficult to navigate.

The surveys concluded that assignments that share any of these attributes make the challenge of recruiting candidates and supporting successful assignments extremely difficult and complex. 
The recruiting tips for potential assignees that derived from the surveys concluded that, at a minimum, MNEs need to prepare answers to the following challenging assignment characteristics:

- location housing,

- family impact,

- premiums and allowances,

- exceptions to policy,

- immigration concerns,

- coping with lesser spoken languages,

- coping with lesser developed cultural contexts,

- medical services availability (or alternatives).

Possibly the most important tip that came from the surveys was the value of developing first-hand knowledge of the growth-market challenges and their solutions (for mobility managers as well as employees and their families).

\section{Research Questions}

The questions raised at the front of this paper are still unanswered. The questions of importance to MNEs seem to centre on identifying characteristics of developing locales that are likely to be important for successful expatriate relocations and from there to identify the characteristics of candidates for relocations to or from emerging markets that will best adapt. From my point-of-view, the following list of traditional IHRM responsibilities presents a focus for IHR managers when delivering expatriate services for expatriates going to or from developing countries.

- recruiting,

- staffing selections,

- relocations,

- expatriate housing,

- immigration, visas,

- incentives and allowances,

- compensation,

- benefits,

- preparation and training,

- language preparation (before and during),

- on-the-ground support,

- family support and education offerings,

- quality of life, 
- safety and security,

- medical and health,

- local employment law,

- government regulation and enforcement,

- repatriation and career advancement.

Each of these areas presents special challenges in most developing countries. As these surveys recognise, the respondents acknowledge that certain markets are less attractive as expatriate destinations. Accordingly, particularly lucrative incentive packages are necessary to attract and retain assignees, for example, to the BRIC countries and Africa. Even with higher support packages and often more expensive support services, success rates at keeping expatriates in emerging-market posts are worse than those experienced in developed country assignments. Obviously, the impact of such failures, in costs, disruption, and lost competitive advantage is immense. And, in a point reiterated often in this paper, E\&Y's report concludes that "[w]hile we have a tendency to view the growth markets as one entity, the constituent nations and regions are not homogenous. As well as straddling several continents, they have diverse political and regulatory systems, contrasting cultures, and varying levels of infrastructure development" (Ernst \& Young 2012b, p. 40).

\section{Bibliography}

Aldrich, G. (2013) "Brookfield Global Relocation Services Global Relocation Trends Survey 2012 - Spotlight on China". International HR Advisor, Summer: 10-13.

Bailey, A. (2010) "New Locations - Next Eleven (N-11)". International HR Advisor, Autumn: 2-3.

Beamish, P. W. (1985) "The Characteristics of Joint Ventures in Developed and Developing Countries". Columbia Journal of World Business 20 (3): 13-19.

Beamish, P. W. (1988) Multinational Joint Ventures in Developing Countries. London / New York: Routledge.

Boyacigillar, N. (1990) "The Role of Expatriates in the Management of Interdependency, Complexity, and Risk in Multinational Corporations". Journal of International Business Studies 21: 265-73.

Brazier, M. (2013) "Survey Shows Growth in International Employee Transfers Fuelled by Emerging Markets". International HR Advisor, Summer: 28-30.

Brewster, C. J. and Mayrhofer, W. (eds) (2012) Handbook of Research on Comparative Human Resource Management. Cheltenham, UK / Northampton, MA: Edward Elgar.

Briscoe, D. R. (2015) "Expatriate Integration and Performance in Emerging Markets" in F. M. Horwitz and P. Budhwar (eds) Handbook of Human Resource Management in Emerging Markets. Cheltenham, UK/ Northampton, MA: Edward Elgar. 
Briscoe, D. R., Schuler, R. S. and Tarique, I. (2012) International Human Resource Management. Fourth edition. London / New York: Routledge.

Budhwar, P. S. and Debrah, Y. A. (2001a) "Introduction" in P. S. Budhwar and Y. A. Debra (eds) Human Resource Management in Developing Countries. London / New York: Routledge.

Budhwar, P. S. and Debrah, Y. A. (eds) (2001b) Human Resource Management in Developing Countries. London / New York: Routledge.

Budhwar, P. S. and Debrah, Y. A. (2010) "Human Resource Management in Developing Countries" in A. Wilkinson, N. Bacon, T. Redman, and S. Snell (eds) The SAGE Handbook of Human Resource Management. London / Thousand Oaks, CA: SAGE Publications.

Budhwar, P., Schuler, R., and Sparrow, P. (eds) (2009) International Human Resource Management. Volumes 1-4. London / Thousand Oaks, CA: SAGE Publications.

Circle Research for the Santa Fe Group (2013) "Key Findings from the 2012 Global Mobility Survey". International HR Advisor, Summer: 8-9.

Collings, D. G. and Scullion, H. (2006) "Approaches to International Staffing" in H. Scullion, and D. G. Collings (eds) Global Staffing. London / New York: Routledge.

Collings, D. G. and Scullion, H. (2012) "Global Staffing” in G. K. Stahl, I. Björkman, and S. Morris Handbook of Research in International Human Resource Management. Second edition. Cheltenham, UK / Northampton, MA: Edward Elgar.

Connelly, C. E. and Gallagher, D. G. (2006) "Independent and Dependent Contracting: Meaning and Implications". Human Resources Management Review 16: 95-106, http:// dx.doi.org/10.1016/j.hrmr.2006.03.008.

Dowling, P. J., Festing, M. and Allen, D. E., Sr. (2013) International Human Resource Management. Sixth edition. Andover, UK: Cengage Learning EMEA.

Ernst \& Young (2012a) Rapid Growth Market Forecast. London: Ernst \& Young Global Limited.

Ernst \& Young (2012b) Global Mobility Effectiveness Survey 2012. London: Ernst \& Young Global Limited.

Fenwick, M. (2005) "Extending Strategic International Human Resource Management Research and Pedagogy to the Non-profit Multinational". International Journal of Human Resource Management 16: 497-512, http://dx.doi. org/10.1080/09585190500051480.

Fisher, S. L., Wasserman, M. E., Wolf, P. P., and Wears, K. H. (2008) "Human Resource Issues in Outsourcing: Integrating Research and Practice". Human Resource Management 47: 501-23, http://dx.doi.org/10.1002/hrm.20229.

Gammeltoft, P. and Tarmidi, L. T. (2013) "Chinese Foreign Direct Investment in Indonesia: Trends, Drivers, and Impacts”. International Journal of Technological Learning, Innovation and Development 6: 136-60, http://dx.doi.org/10.1504/ ijtlid.2013.051701.

Gong, Y. (2003) "Subsidiary Staffing in Multinational Enterprises: Agency, Resources, and Performance". Academy of Management Journal 46: 728-39, http://dx.doi. org/10.2307/30040664.

Harris, M. M. (ed.) (2008) Handbook of Research in International Human Resource Management. New York / London: Lawrence Erlbaum Associates. 
Harvey, M., Speier, C., and Novecevic, M. M. (2001). "A Theory-Based Framework for Strategic Global Human Resource Staffing Policies and Practices". International Journal of Human Resource Management 12: 898-915, http://dx.doi. org/10.1080/09585190122394.

Harzing, A.-W. (2001) "An Analysis of the Functions of International Transfers of Managers in MNCs". Employee Relations 23: 581-98, http://dx.doi. org/10.1108/01425450110409248.

Harzing, A.-W. and Pinnington, A. H. (eds) (2011) International Human Resource Management. Third edition. London / Thousands Oaks, CA: SAGE Publications.

Hauser, J. \& Aldred, G. (2012) "Successful International Assignments into Developing Locations: A Preview of Brookfield GRS' New Spotlight Report”. Strategic Advisor 8 (77): $1-3$.

Hieu, P. D. (2013). "Problems and Conflicts in Managing International Joint Ventures in Vietnam”. Philippine Management Review 20: 47-64.

Horwitz, F. M. and Budhwar, P. S. (eds) (2015) Handbook of Human Resource Management in Emerging Markets. Cheltenham, UK / Northampton, MA: Edward Elgar.

Ibrahim, M. (2010) “Toward a Well-governed Africa”. McKinsey Quarterly, June: 1-5.

Jie, L. (2010) "The Strategy of Talent Localization in Multinational Corporations", http:// www.wenku.baidu.com/view/22a167ee4afe04a1b071def5.html, date of access: 27 October 2012.

Jones, S. (2012) “Transnational Learning and Collaboration in Delivering MBA Programs in Emerging Markets: The Challenge of National Culture" in Information Resources Management Association (ed.) Human Resource Management: Concepts, Methodologies, Tools, and Applications. Three Volumes. Hershey, PA: IGI Global Publishing.

Jung, J. C., Beamish, P. W. and Goerzen, A. (2008) "FDI Ownership Strategy: A Japanese-US MNE Comparison”. Management International Review 48: 491-524, http://dx.doi.org/10.1007/s11575-008-0034-8.

Knowledge at Wharton (2010) "Why Kenya's Elkanah Odembo Believes All Roads Should Lead Investors to Africa", http://knowledge.wharton.upenn.edu/article. cfm?articleid $=2640,23$ November.

Kupka, B., Briscoe, D. R. and Everett, A. M. (2013a) "Influences of International Business Conditions on International Human Resource Strategies for Africa". Paper to the Annual Conference of the Pan Pacific Business Association, Johannesburg, South Africa, 5 June.

Kupka, B., Briscoe, D. R. and Everett, A. M. (2013b) "Preparing Expatriates for Assignment to Growing Markets in Africa". Paper to the Annual Conference of the Pan Pacific Business Association, Johannesburg, South Africa, 5 June.

Ladika, S. (2013) "Expats Lost in Translation". Workforce Management, May: 34-37.

Lewin, A. Y. and Peeters, C. (2006) "The Top-line Allure of Offshoring". Harvard Business Review, March: 22-24.

Li, X., Wang, J. and Liu, X. (2013) "Can Locally-recruited R\&D Personnel Significantly Contribute to Multinational Subsidiary Innovation in an Emerging Economy?". International Business Review. Available (pre-publication) at: http://www.sciencedirect. com/science/article/pii/S0969593112001412, date of access: 6 January 2013. 
Matusik, S. F. and Hill, C. W. L. (1998) "The Utilization of Contingent Work, Knowledge Creation, and Competitive Advantage". Academy of Management Review 23: 680-97, http://dx.doi.org/10.2307/259057.

Maurer, R. (2013a) “International Assignments: Who's Going Where and Why?” http:// www.shrm.org/hrdisciplines/global/articles/pages/ingternational-assignments-survey, date of access: 30 September 2013.

Maurer, R. (2013b) "Millennials Resist Assignments to China, India”. http://shrm.org/ hrdisciplines/global/Articles/Pages/Millennials-Assignments-China, date of access: 15 October 2013.

Meinert, D. (2013) "Expatriate Assignments in Growth Markets to Soar”. HR Magazine, January: 20.

Morris, S. S. and Snell, S. A. (2010) "The Evolution of HR Strategy: Adaptations to Increasing Global Complexity" in A. Wilkinson, N. Bacon, T. Redman, and S. Snell (eds) The SAGE Handbook of Human Resource Management. London / Thousand Oaks, CA: SAGE Publications.

O’Neill, J. (2001) "Building Better Global Economic BRICs". Research Report. New York: Goldman Sachs.

Qi, X. (2013) “Talent Management in Chinese Multinational Corporations”. Master's Thesis. Vassan, Finland: University of Applied Sciences.

Rowley, C. and Warner, M. (eds) (2008) Globalizing International Human Resource Management. London / New York: Routledge.

Roxburgh, C., Dörr. N., Leke, A., Tazi-Riffi, A., van Wamelen, A., Lund, S., Chironga, M., Alatovik, T., Atkins, C., Terfours, N. and Zeino-Mahmalat, T. (2010). "Lions on the Move - The Progress and Potential of African Economies". McKinsey Global Institute Report. New York: McKinsey \& Company.

Ruiz, C. E., Wang, J. and Hamlin, R. G. (2013) "What Makes Managers Effective in Mexico?”. Leadership \& Organizational Development Journal 34: 130-146, http:// dx.doi.org/10.1108/01437731311321904.

Rynes, S., Brief, A. and Walsh, J. (2008) Foreword in M. M. Harris (ed.) Handbook of Research in International Human Resource Management. New York / London: Lawrence Erlbaum Associates.

Salm, J. (1999) "Coping with Globalization: A Profile of the Northern NGO Sector". Nonprofit and Voluntary Sector Quarterly 28: 87-103, http://dx.doi. org/10.1177/089976499773746447.

Scholz, C. and Böhm, H. (eds) (2008) Human Resource Management in Europe. London / New York: Routledge.

Schuler, R. S., Jackson, S. E., Sparrow, P. and Poole, M. (eds) (2004-12). Routledge Global Human Resource Management Series, now including approximately 25 books on various topics in Global HRM, many of which are cited in this bibliography. London / New York: Routledge.

Sim, A. B. (2012) "A Comparative Case Study of the Internationalization Strategies of Malaysian, Singaporean, and Taiwanese Firms". Journal of Asian Business 24 (3): 85-108.

Sparrow, P. (ed.) (2009) Handbook of International Human Resource Management. Chichester, UK: John Wiley \& Sons.

Sparrow, P., Brewster, C. and Harris, H. (2012) Globalizing Human Resource Management. Second edition. London / New York: Routledge. 
Stahl, G. K., Björkman, I. and Morris, S. (eds) (2012) Handbook of Research in International Human Resource Management. Second edition. Cheltenham, UK / Northampton, MA: Edward Elgar.

Stahl, G. K., Miller, E. L. and Tung, R. L. (2002) "Toward the Boundaryless Career: A Closer Look at the Expatriate Career Concept and the Perceived Implications of an International Assignment”. Journal of World Business 37 (3): 216-27, http://dx.doi. org/10.1016/s1090-9516(02)00080-9.

Thite, M., Wilkinson, A., and Budhwar, P. (2011a) HRM Strategies and Practices across Subsidiaries in Multinational Corporations from Emerging Economies - An Indian Perspective. SHRM Foundation Research Report, http://www.shrm.org/about/ foundation/research/Pages/SHRMFoundationResearchThite.aspx, date of access: 24 May 2011.

Thite, M., Wilkinson, A., and Budhwar, P. (2011b) Internationalization of India, Inc. SHRM Research Report. Alexandria, VA: SHRM.

Thomas, D. C. \& Lazarova, M. (2013) Essentials of International Human Resource Management: Managing People Globally. Thousand Oaks, CA: SAGE Publications.

Tung, R. L. (1981) "Selection and Training of Personnel for Overseas Assignments". Columbia Journal of World Business 23: 129-43.

United Nations Human Development Reports (2011) Human Development Index. http:// hdr.undp.org/en/media/HDR_2011_EN.pdf, date of access: 1 October 2011.

Wilkinson, A., Bacon, N., Redman, T. and Snell, S. (eds) (2010) The SAGE Handbook of Human Resource Management. London / Thousand Oaks, CA: SAGE Publications.

Yao, C. D. (2013) Experiencing International Assignment: An Exploratory Study of Chinese International Assignees. Thesis for partial fullfilment of the requirements for the degree of Doctor of Philosophy in Human Resource Management at Massey University, Albany, New Zealand, http://hdl.handle.net/10179/4917, date of access: 10 October 2013.

\section{Abstract}

\section{Ekspatriacja na rynkach wschodzących - wyzwania międzynarodowego zarządzania zasobami ludzkimi}

Międzynarodowy biznes coraz większą wagę przywiązuje do rynków rozwijających się oraz rynków wschodzących. Do tej pory większość badań z zakresu międzynarodowego zarządzania zasobami ludzkimi skupiała się na procesie zarządzania misjami zagranicznymi, przeprowadzanymi przez centrale przedsiębiorstw międzynarodowych ulokowanych w krajach rozwiniętych, do ich oddziałów w innych rozwiniętych krajach. W badaniach rzadko skupiano się na procesie ekspatriacji na rynki wschodzące, a jeszcze rzadziej - na szczegółowych aspektach tego procesu. Artykuł zawiera przegląd literatury przedmiotu z zakresu procesu ekspatriacji, przeprowadzanej przez przedsiębiorstwa międzynarodowe z krajów rozwiniętych do ich oddziałów na rynkach wschodzących, a także na ogólnym zarysie współczesnych trendów opisanych w literaturze przedmiotu, dotyczących funkcjonowania ekspatriantów na rynkach wschodzących. Zdefiniowano termin „rynki wschodzące” oraz określono zakres jego zastosowania. 
W praktyce bowiem aktualne rozumienie tego terminu, przedstawiane we wszelkiego rodzaju dyskusjach oraz badaniach, jest zbyt szerokie. Przedstawiono także dorobek w zakresie ekspatriacji z rynków rozwiniętych na rynki wschodzące, a także poddano ocenie porównanie praktyk z zakresu ekspatriacji w krajach rozwiniętych oraz na rynkach wschodzących. Przeanalizowano również nowy trend, polegający na wysyłaniu przedstawicieli przedsiębiorstw międzynarodowych wywodzących się z rynków wschodzących do oddziałów firmy zlokalizowanych na innych rynkach wschodzących bądź w krajach rozwiniętych. Artykuł kończą wnioski sformułowane na podstawie badań prowadzonych przez firmy konsultingowe, poświęcone wyzwaniom, przed jakimi stoją obecnie przedsiębiorstwa międzynarodowe decydujące się na realizację misji zagranicznych na rynkach wschodzących, a także ocena - czy te doświadczenia różnią się od zdobywanych wcześniej podczas misji zagranicznych w krajach rozwiniętych. Przedstawiono też propozycje rozwiązań, z jakich mogą skorzystać przedsiębiorstwa napotykające te wyzwania.

Słowa kluczowe: przedsiębiorstwa międzynarodowe, rynki wschodzące, ekspatriacja, międzynarodowe zarządzanie zasobami ludzkimi. 